\title{
UTILIZATION OF PEACH AND TOMATO WASTES AS UNCONVENTIONAL SOURCES OF EDIBLE OILS AND NATURAL ANTIOXIDANTS
}

\author{
AMAL M. EL-BASTAWESY ${ }^{1}$, A. A. EL-REFAI ${ }^{2}$ AND M.Z.M. MOUSTAFA $^{1}$
}

1. Food Technology Research Institute, ARC, Giza

2. Food Industries Dept., Fac. of Agric., Mansoura Univ., Egypt

(Manuscript received 11 June 2007)

\begin{abstract}
Recycling some waste materials especially, peach and tomato seeds to beneficial materials with high nutritional and functional properties as well as, unconventional sources of edible oils with highly antioxidative properties was the main target of this study. The obtained results revealed that peach seeds had the highest content of oil ( $43.5 \%$ ), and the chemical properties were in the normal range of edible oils. The percentage of the unsaturated fatty acids of peach and tomato seeds oils were high (92.677 and $83.370 \%$, respectively) especially, essential fatty acids ( Linoleic , Omega 6 ), which reflects good nutritional value of these oils. The oxidative stability of sunflower oil increased with increasing the levels of peach methanolic extract up to $400 \mathrm{ppm}$ that exhibited the best oxidative stability and prolonged the shelf life of sunflower oil to 12.5 months. The highest oxidative stability ( 8.84 hr.) was obtained using tomato methanolic extract at level of 600 ppm compared with those obtained with other levels. Shelf life and antioxidant activity of sunflower oil increased gradually with increasing the tomato methanolic extract levels (11.03 to 12.67 hrs and 1.02 to 1.18 , respectively). Furthermore, lycopene crude extract acted as pro-oxidant in higher levels, meanwhile, lower levels of lycopene extract ( 20 and 40 ppm) had an antioxidant effects on the stability of sunflower oil.

From the obtained results, it could be concluded that peach and tomato seeds are considered rich sources of edible oils and natural antioxidants that play a great role in protecting human body. Utilization of these wastes will improve the environmental ecology of industry by recycling its by-products and decrease the problems of pollution from industrial wastes.

Key words: Peach seed oil , Tomato seed oil , Lycopene, Fatty acids composition, Natural antioxidants and Oxidative stability
\end{abstract}

\section{INTRODUCTION}

Peach ( Plunus persica ) and tomato fruits (Lycopersicun esculentum) are considered as the most popular fruits and vegetables grown and processed in Egypt . The average total annual cultivated area with these fruits in the year 2004 were 79199 and 464491 feddans producing annually 332020 and 7640818 tons for peach and tomato, respectively (Anon, 2005). Kernels and seeds are the most important wastes discarded following the industrial processing of fruit and vegetable juices. Large quantities of solid wastes are being left over and disposal of these waste 
materiais becomes difficult and pose serious problems. The plentiful amounts of tomato wastes and peach seeds remaining after processing represent about $10-16$ $\%$ of the total fresh weight of tomato and peach fruits (Hussein, 2002). Many investigators demonstrated that such wastes are rich sources of edible oils (ELBastawesy et al., 2007), antioxidant compounds (Hemeda, 1994) and natural pigments ( El-Seesy and Hamed , 1998).

Peach kernels contained 48.0- $54.5 \%$ oil and $25.0-27.5 \%$ protein, $12.59-25.2$ $\%$ total carbohydrates, $2.9-3.42 \%$ crude fibers, $2.55-3.6 \%$ ash and adequate amounts of minerals (Allam, 2001 and Hussein, 2002 ). Total saturated and unsaturated fatty acids of peach seeds oil were $11.69 \%$ and $88.31 \%$, respectively (Allam, 2001). Furthermore, fatty acids composition of peach seeds oil indicate that oleic acid ( $76.6 \%$ ) was the predominant fatty acid followed by linoleic acid $(13.4 \%)$, palmitic acid $(8.6 \%)$, linolenic acid $(0.9 \%)$. This means that peach kernels oil is characterized by its high nutritional value because it is rich in essential fatty acids oleic and linoleic. Physical and chemical characteristics of peach kernels oil were almost the same as almond kernels oil which can be used as low price byproduct oil instead of the more expensive almond kernels oil in cosmetics and medical uses (Allam, 2001 and Hussein, 2002 ).

The tomato seeds contained $3.85-4.06 \%$ ash, $23.53-25.10 \%$ oil and 35.52 $35.56 \%$ protein on dry weight basis. Minerals present in these seeds were calcium $(800)$, sodium (2200), potassium (2700), magnesium (9600), iron (120), zinc (50), copper (20), manganese (20), phosphate (7784) mg/100 gm on dry weight basis (Persia et al., 2003). Moreover, Giannelos et al. (2005) found that the fatty acids composition of tomato seeds oil was nearly the same as in the edible cotton seed oil and can be used in the food products. Total saturated and unsaturated fatty acids were $13.7-24.83$ and $75.13-86.6 \%$, respectively. Also, the predominant essential fatty acids of tomato seeds oil were linoleic ( $44.1-58.12 \%$ ) and oleic ( $17.01-42.0$ $\%$ ). As well as, the chemical composition of the seeds may give an indication to the economy of using these wastes as sources of oil or protein. (Sogi et al., 2004).

Fruits and vegetables are the main sources of natural antioxidants such as phenolic compounds, vitamins ( $E$ and $A$ ) and lycopene that protect human body and it can be used in the food industries. George et al. ( 2004) found that total phenolic contents of tomato seeds as catechine ranged from 188 to $465 \mathrm{mg} / 100 \mathrm{gm}$, on dry weight basis. On the other hand, the total phenolic contents of tomato waste as gallic acid were in the range of $12.15-49.61 \mathrm{mg} / \mathrm{gm}$ dry residue ( Toor and Savage, 2005). The lycopene content was $4.8-14.1 \mathrm{mg} / 100 \mathrm{gm}$ in tomato peel on fresh weight basis and $63.3-138.87 \mathrm{mg} / 100 \mathrm{gm}$ on dry weight basis ( George et 
al.,2004, Radwan et al ., 2004 and Toor and Savage , 2005). Addition of lycopene to sunflower oil would improve the stability of oil as well as protect the human health from the risk of some dangerous diseases.

Accordingly, the present work was planned to study the utilization of peach and tomato seeds as unconventional sources of edible oils with highly antioxidative properties. Moreover, the efficiency of their methanolic extracts as sources of natural antioxidants was evaluated for industrial application.

\section{MATERIALS AND METHODS}

1- Materials

- Peach seed kernels and tomato seeds, as food processing wastes obtained after juice extraction, were used in this investigation .

- kernels of peach fruits ( Prunus persica ) variety Clingestone (Sultani) were obtained from an orchard near Kaluobia Governorate, Egypt .

- Seeds of tomato fruits ( Lycopersicun esculentum ) were obtained from Egyptian Canning Company (Best), Meniat Samannud, Aga , Dakahlia Governorate, Egypt. - Refined sunflower oil (antioxidant free ) was purchased from Misr Company for Oil and Soap, El Mansoura, Egypt .

- Butelated hydroxy toluene (BHT) was purchased from Sigma Chemicals Company .

2. Methods

\subsection{Preparation of raw materials}

Wastes seeds used in this study were washed by tab water and dried in an air circulated oven at $60^{\circ} \mathrm{C}$ for 12 hrs to moisture content less than $10 \%$. The obtained dried materials were milled using Braun mill machine, sieved through 21 mesh screen , packaged in polyethylene bags and stored in refrigerator $\left(-4 \pm 1^{\circ} \mathrm{C}\right)$ for analysis .

\subsection{Analytical methods}

\subsubsection{Chemical properties}

- Moisture, ash , protein , crude fat and crude fibers contents and hydrocyanic acid were determined according to the methods described by the AOAC (2000).

- Available carbohydrates and energy values contents were calculated according to James ( 1995 ). Minerals ( $\mathrm{Na}, \mathrm{K}, \mathrm{Ca}, \mathrm{Mg}, \mathrm{Fe}$ and $\mathrm{Zn}$ ) were determined after dry ashing according to the method described by the AOAC (2000), using Atomic absorption ( Perkin - Elmer , Model 3300, USA). Tannins and phytic acid were determined according to the methods described by Ranganna (1979).

-Chlorophyll ( $\mathrm{a}$ and $\mathrm{b}$ ) and total carotenoids of tomato peel were determined according to the methods described by Dere et al. (1998). 


\subsubsection{Extraction and determination of lycopene}

Lycopene content was extracted and determined according to Ranganna (1979).

\subsubsection{Extraction of crude oils}

Grounded peach and tomato seeds were soaked in hexane at room temperature for 24 hours, then the micella ( oil + hexane ) was filtrated through filter paper (Whatman No.1) and evaporated using rotary evaporator to obtain the oil from hexane micella. Sodium sulphate anhydrous was added to the oil $(0.1 \%, w / v)$ to remove the traces of moisture. The oil was stored in dark bottles in refrigerator at$4^{\circ} \mathrm{C}$ for analysis .

2.2.4. Some chemical properties of crude oils

Acidity \% (as oleic acid), peroxide and iodine values were determined in all extracted crude oils and sunflower oil according to the methods described by the AOAC (2000) .

\subsubsection{Fatty acids composition analysis}

Gas liquid chromatography (Agilent $6890 \mathrm{GC}$, USA) was used for determination and identification of the fatty acids methyl esters according to the method described by Zygadlo et al. (1994), at the Central Laboratory of Food Technology Research Institute, Giza , Egypt .

\subsubsection{Extraction and determination of total phenolic compounds}

Milled sample $(20 \mathrm{gm})$ was extracted over night with $200 \mathrm{ml}$. methanol at room temperature. Total phenolic contents were determined using the Folin Ciocalteau reagent according to the method described by Kaur and Kapoor ( 2002 ).

\subsubsection{Fractionation and identification of phenolic compounds}

Phenolic compounds of methanolic extracts were passed through micro-filter $0.45 \mu \mathrm{m}$ and identified using high performance liquid chromatography (HPLC), Hewelt-Packard (Model hp 1050), according to the method described by Gertz (1990). The separation and determination were performed on C18 column (150×4.6 $\mathrm{mm}$ ). The mobile phase yielded results of (methanol: water: acetic acid, $40: 59.3$ : $0.7, \mathrm{v} / \mathrm{v} / \mathrm{v}$ ). The wave length in the UV detector was $254 \mathrm{~nm}$. Total run time for the separation was approximately $25 \mathrm{~min}$ at a flow rate of one $\mathrm{ml} / \mathrm{min}$. Phenolic compounds of each sample were identified by comparing their relative retention times with those of the standard mixture chromatogram . The concentration of an individual compounds was calculated on the basis of peak area measurement, then converted to $\mathrm{mg}$ phenolic/100 gm dry matter. 


\subsubsection{Determination of antioxidant activity}

The dried methanolic extracts of seeds and extracted lycopene at levels of $200,300,400$ and 600 ppm and 20,40,200, 300 and 400 ppm, respectively and BHT $(200 \mathrm{ppm})$ were mixed well with sunflower oil using magnetic stirrer to complete dispersion in the oil. Sunflower oil sample was kept without any additives as a control. The antioxidant activity was determined by the Rancimat method using Rancimat Metrohm 679 as described by Hasenhuttle and Wan (1992) and the induction period (I.P.) was conducted with Rancimat at $100^{\circ} \mathrm{C}$ and calculated at $25^{\circ} \mathrm{C}$ using the temperature coefficient of 2.2 for induction period and 2.5 for expired period. The antioxidant activity and increasing index were calculated using the following equation:

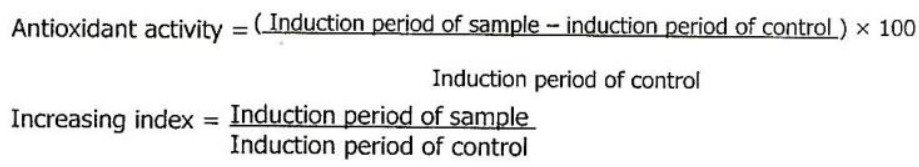

\section{RESULTS AND DISCUSSION}

\section{1- Chemical properties of peach and tomato seeds}

Data presented in Table ( 1 ) reveal that peach seed kernels contained $3.155 \%$ ash, $22.647 \%$ protein, $43.137 \%$ fat, $9.282 \%$ crude fibers and $13.646 \%$ carbohydrates. These data are in agreement with those found by Allam (2001). Tomato seeds had $4.226 \%$ ash, $28.636 \%$ protein, $26.241 \%$ fat , $19.831 \%$ crude fibers and $14.119 \%$ carbohydrates on dry weight basis. These results are in accordance with those of Persia et al. (2003). From the data presented in the same table some antinutritional substances in peach and tomato seeds were also detected. Peach seed kernels and tomato seeds contained traces amounts of hydrocyanic acid ( $\mathrm{HCN}$ ) $(0.157 \%$ and $0.063 \%$, respectively). The HCN content of peach seed kernels was in the range detected by Hussein (2002), who found that $\mathrm{HCN}$ content of peach seed kernels ranged from 0.112 to $0.19 \% \mathrm{HCN}$. On the other hand, tomato seeds contained $0.063 \% \mathrm{HCN}$. Tannin content of peach seeds kernels was $(0.497 \%)$, but no tannin was detected in tomato seeds. The peach seed had lower content of phytic acid than tomato seeds which was $1.36 \%$ on dry weight basis. Also, from the aforementioned data, it could be clearly noticed that tomato seeds had higher contents of potassium and magnesium (302.52 and $242.212 \mathrm{mg} / 100 \mathrm{gm}$ ), respectively than peach seeds. Calcium, iron and zinc contents of both tested seeds were found in a large portion. Peach seeds had the highest content of iron, which 
represents about three folds of that found in tomato seeds. Besides, peach and tomato seeds had zinc contents of 147.845 and $200.543 \mathrm{mg} / 100 \mathrm{gm}$, respectively.

\section{2-Carotenoids in tomato peel}

Carotenoids play a great role in protecting the body against oxidizing agents, mutagens and carcinogens (El-Seesy and Hamed,1998). Therefore, the total carotenoids and their fractions, chlorophyll $a$ and $b$ and lycopene contents of tomato peel were determined and the results are given in Table ( 2 ). From these data, it could be observed that tomato peel had high contents of chlorophyll $a$ and $b$ ( 10.04 and $12.76 \mathrm{mg} / 100 \mathrm{gm}$, respectively ). Lycopene is the predominant carotenoid in tomato peel $(157.531 \mathrm{mg} / 100 \mathrm{gm}$ ). Also, total carotenoids content was $4392.74 \mathrm{mg}$ / $100 \mathrm{gm}$. These results are near to those reported by Radwan et al. ( 2004 ), who found that tomato peel lycopene content was $138.87 \mathrm{mg} / 100 \mathrm{gm}$ dry matter.

Table 1 . Chemical composition of peach and tomato seeds

\begin{tabular}{|c|c|c|}
\hline Constituents\% Seeds & Peach & Tomato \\
\hline Moisture & 8.133 & 6.947 \\
\hline Protein & 22.647 & 28.636 \\
\hline Fat & 43.137 & 26.241 \\
\hline Crude fibers & 9.282 & 19.831 \\
\hline Available carbohydrates & 13.646 & 14.119 \\
\hline $\begin{array}{c}\text { Energy value (K cal / gm) } \\
\text { dry matter }\end{array}$ & 533.405 & 407.189 \\
\hline Tannins & 0.497 & 0.00 \\
\hline Phytic acid & 0.437 & 1.360 \\
\hline HCN & 0.157 & 0.063 \\
\hline Ash & 3.155 & 4.226 \\
\hline Minerals: & 39.829 & 16.4283 \\
\hline (mg/ 100 gm ) & 248.090 & 302.520 \\
\hline Sodium & 169.625 & 242.212 \\
\hline Potassium & 624.264 & 577.581 \\
\hline Magnesium & 84.115 & 39.625 \\
\hline Calcium & 147.875 & 200.543 \\
\hline Iron & & \\
\hline Zinc & & \\
\hline
\end{tabular}

* ( on dry weight basis ) 
Table 2. Carotenoids content of tomato peel.

\begin{tabular}{|c|c|}
\hline Carotenoids* $^{*}$ & Tomato peel \\
\hline Chlorophyll a & 10.0400 \\
\hline Chlorophyll b & 12.764 \\
\hline Lycopene & 157.531 \\
\hline Total carotenoids & 4392.738 \\
\hline
\end{tabular}

* ( $\mathrm{mg} / 100 \mathrm{gm}$ on dry weight basis )

\section{3-Chemical properties of extracted peach and tomato seeds oils}

Peach and tomato seeds oils were extracted and some chemical properties are presented in Table ( 3 ). From these results, it was found that peach seeds had higher oil content ( $43.14 \%$ ) than that of tomato seeds ( $26.41 \%$ ). This high content of oil encourage the researchers to evaluate the extracted oils. Acidity, peroxide and iodine values were determined, compared with those of refined sunflower oil ( SFO). Such properties would give an indication about the possibility and suitability of uses of the produced crude seeds oils, either for edible or industrial purposes . Acidity of all examined seeds oils were higher than those of refined SFO $(0.164 \%)$. In addition acid value of peach seeds oil $(0.407 \%)$ was higher than that reported by Hussein (2002) and near to the value mentioned by Allam ( 2001). Also, acid value of tomato seeds oil ( $2.30 \%$ ) was lower than the values mentioned in the literature. The peroxide values of extracted crude oils were 6.43 and 3.271 meq. $\mathrm{O}_{2} /$ $\mathrm{kg}$ for peach and tomato seeds, respectively. These values showed that no oxidation have taken place in the extracted crude oils. Iodine values of peach and tomato crude oils were 103.553 and 111.528 , respectively. From the aforementioned data, it could be concluded that peach and tomato crude oils are considered as semi dried oils. Iodine value of peach seed kernels oil was close to the values reported by Allam ( 2001 ) and Hussein ( 2002 ). Moreover, iodine value of tomato seeds oil was in agreement with those reported by Persia et al. (2003).

Generally, it could be concluded that the studied extracted seeds oils had chemical properties in the normal range of edible oils . 
UTILIZATION OF PEACH AND TOMATO WASTES AS UNCONVENTIONAL SOURCES OF EDIBLE OILS AND NATURAL ANTIOXIDANTS

Table 3. Crude oils content and some chemical properties of extracted peach and tomato seeds oils.

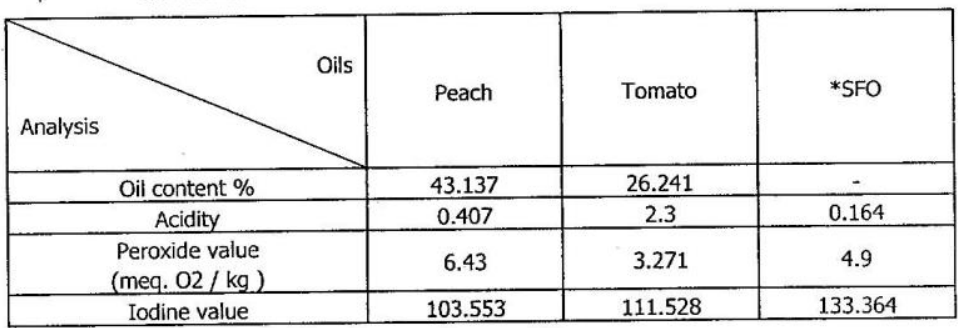

*SFO $=$ Refined sunflower oil .

\section{4- Fatty acids composition of extracted crude oils}

The fatty acids composition of extracted peach and tomato seeds crude oils were separated and identified using GLC and the results are given in Table (4). The results show that peach kernels oil contained the highest content of total USFA ( $92.677 \%)$ and the most abundant fatty acids in MUSFA was oleic acid ( $71.685 \%$ ). Meanwhile , reasonable amount of linoleic acid ( $20.805 \%$ ) and lower content of total SFA (7.323 \%) as palmitic acid ( $7.217 \%$ ), beside trace amount of arachidic acid $(0.106 \%)$ were also detected in peach kernels oil. These data are near to those of Allam (2001) and Hussein ( 2002 ). Six fatty acids of tomato seeds oil were identified and the results are shown in Table ( 4 ). The total USFA content ( 83.370 $\%$ ) was increased compared with total SFA content ( $16.630 \%)$. Linoleic acid represented the major part ( $58.327 \%$ ) of total USFA followed by oleic acid ( 22.66 $\%$ ) and lower amount of PUSFA as linoleic acid ( $2.383 \%$ ) was detected. Tomato seeds oil was the highest of palmitic acid content ( $13.365 \%$ ) compared with that of other tested oils. These data are in accordance with those of Giannelos et al . (2005) . From the aforementioned data, it could be clearly observed that the percentage of the unsaturated fatty acids of peach and tomato seeds oils were high and reached approximately $93 \%$, specially, essential fatty acids ( linoleic, Omega 6 ) which reflect the nutritional value of these oils.

\section{5- Total phenolic compounds of peach and tomato seeds}

Total phenolic compounds of peach and tomato seeds were determined and the results are shown in Table (5). From these results, it was found that the total phenolic compounds detected in tomato seeds ( $68.939 \mathrm{mg} / 100 \mathrm{gm}$ ) were lower than those detected in peach seed kernels $(89.628 \mathrm{mg} / 100 \mathrm{gm})$. Meanwhile, tomato seed total phenolic compounds content was higher than those of Toor and Savage (2005) and lower than the value reported by George et al. (2004). 


\section{6-Fractionation of phenolic compounds}

Data in Table (6) show the fractions of phenolic compounds of peach and tomato seeds. As recorded in the same table it could be clearly noticed that there are four fractions of phenolic compounds found in peach seed kernels, in lesser amounts , were pyrogallic acid ( 0.026$)$, hydroquinone ( 0.024$)$, gallic acid ( 0.304 ) and rutin ( 1.295 ) $\mathrm{mg} / 100 \mathrm{gm}$ dry seeds. As regard to tomato seeds, five fractions of phenolic compounds were gallic acid, resorcinol, protocatechuic, chlorogenic and kaempferol $(15.505,9.754,0.730,0.758$ and $0.470 \mathrm{mg} / 100 \mathrm{gm}$, respectively). Furthermore, gallic acid is the predominant phenolic compound of tomato seeds.

Table 4. Fatty acids composition of peach and tomato seeds oils .

\begin{tabular}{|c|c|c|}
\hline Oils & Peach & Tomato \\
\hline $\begin{array}{c}\text { Fatty acids \% } \\
\text { C16:0 }\end{array}$ & 7.217 & 13.365 \\
\hline $\begin{array}{c}\text { Stearic acid } \\
\text { C18:0 }\end{array}$ & -- & 3.165 \\
\hline $\begin{array}{c}\text { Oleic acid } \\
\text { C18:1 }\end{array}$ & 71.685 & 22.660 \\
\hline $\begin{array}{c}\text { Linoleic acid } \\
\text { C18:2 }\end{array}$ & 20.805 & 58.327 \\
\hline Linotenic acid \\
C18:3
\end{tabular}


Table 5. Total phenolic compounds content of peach and tomato seeds .

\begin{tabular}{|c|c|}
\hline Samples & $\begin{array}{c}\text { Total phenolic content } \\
*(\mathrm{mg} / 100 \mathrm{gm})\end{array}$ \\
\hline Peach seeds & 89.628 \\
\hline Tomato seeds & 68.939 \\
\hline
\end{tabular}

On dry weight basis.

Table 6. Fractions of phenolic compounds of peach and tomato seeds methanolic extracts .

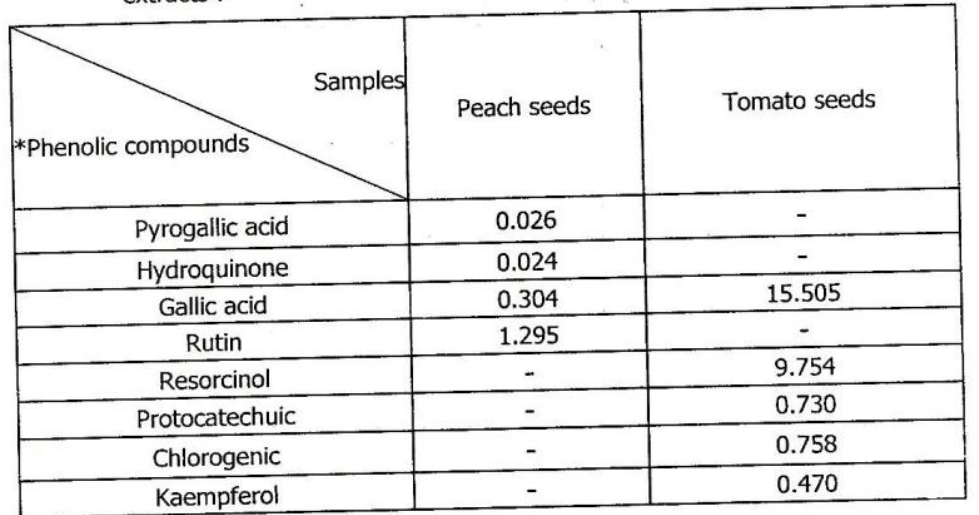

* mg / 100 gm dry matter

7-The effect of phenolic extracts on oxidative stability of sunflower oil

Forced oxidative conditions were used to determine the effect of addition peach and tomato seeds methanolic extracts, as well as lycopene on shelf life or oxidative stability of SFO and the results are shown in Tables ( 7,8 and 9).

\section{1-Peach seed kernels}

Peach seed kernels methanolic extract (PME) was added at levels of 200, 300 , 400 and $600 \mathrm{ppm}$ to sunflower oil to study its antioxidant activity and the results are shown in Table (7). The results reveal that the oxidative stability of sunflower oil was increased with increasing the level of PME until $400 \mathrm{ppm}$ that exhibited the best oxidative stability and increased the shelf life of sunflower oil to 12.5 months. After that, increasing the PME level ( 600 ppm ) decreased the oxidative stability of sunflower oil compared with that obtained with other levels. Also, it can be observed that BHT had higher antioxidant activity ( 1.26 ) than that of peach seed kernels methanolic extract. The low oxidative stability of PME may be due to its lower content of total phenolic compounds as previously shown in Table ( 9 ). 
Table 7. Effect of peach seed kernels methanolic extract on oxidative stability of sunflower oil .

\begin{tabular}{|c|c|c|c|c|c|}
\hline \multirow{2}{*}{$\begin{array}{c}\text { Extracts } \\
\text { levels }\end{array}$} & $\begin{array}{c}\text { Induction period } \\
\text { at100C } \\
\text { (hours ) }\end{array}$ & $\begin{array}{c}\text { Expired period at } \\
25^{\circ} \mathrm{C} \\
\text { (months) }\end{array}$ & $\begin{array}{c}\text { Shelf life at } \\
25^{\circ} \mathrm{C} \\
\text { (months })\end{array}$ & $\begin{array}{c}\text { Antioxidant } \\
\text { activity }\end{array}$ & $\begin{array}{c}\text { Increasing } \\
\text { index\% }\end{array}$ \\
\hline Control & 7.265 & 4.030 & 10.780 & - & - \\
\hline $\operatorname{BHT}(200 \mathrm{ppm})$ & 9.140 & 5.070 & 13.560 & 1.260 & 25.810 \\
\hline $\operatorname{PME}(200 \mathrm{ppm})$ & 7.965 & 4.416 & 11.820 & 1.100 & 9.640 \\
\hline $\operatorname{PME}(300 \mathrm{ppm})$ & 8.090 & 4.485 & 12 & 1.114 & 11.360 \\
\hline $\operatorname{PME}(400 \mathrm{ppm})$ & 8.425 & 4.671 & 12.500 & 1.160 & 15.970 \\
\hline $\operatorname{PME}(600 \mathrm{ppm})$ & 6.500 & 3.664 & 9.642 & 0.895 & -0.105 \\
\hline
\end{tabular}

\section{2-Tomato seeds}

Data presented in Table (8) reveal that there is a positive relationship between oxidation stability of sunflower oil and increasing the tomato seeds methanolic extract (TME) levels. The highest oxidative stability ( $8.84 \mathrm{hr}$. ) was obtained using of TME at level $600 \mathrm{ppm}$ compared with those of the other levels. Shelf life and antioxidant activity of sunflower oil were increased gradually with increasing the TME levels (11.03 to 12.67 months and 1.02 to 1.18 , respectively ). These results are in agreement with those reported by Hemeda ( 1994 ). Accordingly, from data shown in the same table, it can be seen that addition of BHT ( 200 ppm ) had a higher effect on the oxidative stability of sunflower oil than those occurred with TME. This may be due to lower content of total phenolic compounds TME compared with other tested seeds.

\section{3-Crude lycopene extract}

Data in Table (9) show the effect of addition of crude lycopene extract with levels $20,40,200,300$ and 400 ppm on the oxidative stability of sunflower oil. The addition of $\mathrm{BHT}(200 \mathrm{ppm}$ ) resulted in the highest induction period ( $9.14 \mathrm{hr}$. ) and increased shelf life to 13.56 months. On the other hand, lycopene crude extract acted as pro-oxidant in higher concentrations ( 200, 300 and $400 \mathrm{ppm}$ ), which had induction periods $4.86,4.63$ and 6.65 hrs. , respectively. Meanwhile, lower levels of lycopene extract ( 20 and 40 ppm ) had an antioxidant effects on the stability of 
Table 8. Effect of tomato seeds methanolic extract on oxidative Stability of sunflower oil .

\begin{tabular}{|c|c|c|c|c|c|}
\hline \multirow{2}{*}{$\begin{array}{c}\text { Extracts } \\
\text { levels }\end{array}$} & $\begin{array}{c}\text { Induction } \\
\text { period at } \\
100^{\circ} \mathrm{C} \\
\text { (hours })\end{array}$ & $\begin{array}{c}\text { Expired period at } \\
25^{\circ} \mathrm{C} \\
(\text { months })\end{array}$ & $\begin{array}{c}\text { Shelf life at } 25^{\circ} \mathrm{C} \\
\text { (months) }\end{array}$ & $\begin{array}{c}\text { Antioxidant } \\
\text { activity }\end{array}$ & $\begin{array}{c}\text { Increasing index } \\
\%\end{array}$ \\
\hline Control & 7.265 & 4.030 & 10.780 & - & - \\
\hline BHT( $200 \mathrm{ppm})$ & 9.140 & 5.070 & 13.560 & 1.260 & 25.810 \\
\hline TME (200 ppm) & 7.435 & 4.122 & 11.030 & 1.020 & 2.340 \\
\hline TME (300 ppm) & 7.870 & 4.363 & 11.670 & 1.080 & 8.330 \\
\hline $\operatorname{TME}(400 \mathrm{ppm})$ & 8.330 & 4.620 & 12.360 & 1.150 & 14.660 \\
\hline $\operatorname{TME}(600 \mathrm{ppm})$ & 8.535 & 4.734 & 12.664 & 1.175 & 17.481 \\
\hline
\end{tabular}

sunflower oil which had induction periods of 8.05 and 7.69 hrs. , respectively. Also, the levels of lycopene crude extract 20 and $40 \mathrm{ppm}$ had an antioxidant activity (1.11 and 1.06 , respectively), compared with those of $\mathrm{BHT}(1.26)$. These results are in agreement with those reported by Radwan et al. ( 2005 ), who found that lycopene concentration ( $20 \mathrm{ppm}$ ) have induction period of 10 hours while $80 \mathrm{ppm}$ had 9.57 hours. Therefore, there is an adverse relationship between concentration and induction period when lycopene added to sunflower oil . Galicia et al. ( 2005 ) studied the stability of lycopene added to canola oil, which reported that the oxidized pigment probably acts as pro-oxidant. Also, lycopene is stable against photo oxidation of canola oil. Maforimbo ( 2002 ), reported that carotenoids seemed to be effective in retarding oil peroxidation under photo oxidation, while showing pro-oxidant activity under oven heating auto oxidation and showing slight antioxidant activity under Rancimat auto-oxidation tests .

Finally, it could be concluded that both peach seed kernels and tomato seeds oils have complex mixture of components with antioxidant properties. The compositional factors of peach seeds oils, moderate content of linoleic acid and low content of the easily oxidized linolenic acid, that contribute to its good behavior as frying oil. 
Table 9. Effect of lycopene crude extract on oxidative stability of sunflower oil .

\begin{tabular}{|c|c|c|c|c|c|}
\hline \multirow{2}{*}{$\begin{array}{c}\text { Extracts } \\
\text { levels }\end{array}$} & \multicolumn{5}{|c|}{ Oxidative stability } \\
\cline { 2 - 6 } & $\begin{array}{c}\text { Induction period at } \\
100^{\circ} \mathrm{C} \\
\text { (hours) }\end{array}$ & $\begin{array}{c}\text { Expired period at } \\
25^{\circ} \mathrm{C} \\
\text { (months) }\end{array}$ & $\begin{array}{c}\text { Shelf life } \\
\text { at } 25^{\circ} \mathrm{C} \\
\text { (months) }\end{array}$ & $\begin{array}{c}\text { Antioxidant } \\
\text { activity }\end{array}$ & $\begin{array}{c}\text { Increasing } \\
\text { index\% }\end{array}$ \\
\hline Control & 7.265 & 4.030 & 10.780 & - & - \\
\hline BHT(200ppm) & 9.140 & 5.070 & 13.560 & 1.260 & 25.810 \\
\hline LCE 20 ppm & 8.050 & 4.465 & 11.945 & 1.110 & 11 \\
\hline LCE $40 \mathrm{ppm}$ & 7.690 & 4.266 & 11.411 & 1.060 & 6 \\
\hline LCE $200 \mathrm{ppm}$ & 4.865 & 2.70 & 7.220 & 0.669 & - \\
\hline LCE $300 \mathrm{ppm}$ & 4.630 & 2.570 & 6.869 & 0.637 & - \\
\hline LCE $400 \mathrm{ppm}$ & 6.650 & 3.690 & 9.870 & 0.915 & - \\
\hline
\end{tabular}

\section{REFERENCES}

1. Allam, S. M. 2001. Physicochemical characterization, fatty acids composition and oxidative stability of some seed kernels oils of prunus genus., Assiut J. of Agric. Sci., 32(1)37-46.

2. Anonymous. 2005. Agricultural statistics, Part 2 , Ministry of Agriculture and Land Reclamation, Egypt.

3. AOAC. 2000. Association of Official Analytical Chemists. Official Methods of Analysis . ( $17^{\text {th }}$ Ed. ), Washington, DC,USA.

4. Dere, S., T. Güneş and R. Sivaci. 1998. Spectrophotometric determination of chlorophyll - a , b and total carotenoid contents of some algae species using different solvents. Turkish J. of Botany, 22:13-17.

5. El-Bastawesy, Amal M., A. A. EL-Refai and M. M. Zakaria. 2007. Grape and mango seeds as untraditional sources of edible oils, antioxidants and antibacterial compounds. $9^{\text {th }}$ International Conference on chemistry and its role in development. 16-19 April 2007, Fac. of Sci., Mansoura Univ., Egypt

6. El-Seesy, T. A. and H. S. Hamed. 1998. Utilization of lycopene extracted from tomato wastes in coloring sausage. Egyptian J. Appl. Sci., 13(12):117-129.

7. George, B., C. Kavr, D. Khurdiya and H. Kapoor. 2004. Antioxidants in the tomato ( Lycopersicum esculentum ) as a function of genotype. Food Chem. ,84:45-51.

8. Gertz, C. H. 1990. HPLC tips and tricks . Great Britain Idden Press, Oxford . pp. 608.

9. Giannelos, P., S. Sxizas, F. Zannikos and G. Anastopoulos. 2005. Physical, chemical and fuel related properties of tomato seeds oil for evaluating its direct use in diesel engines. Industrial Crops and Products , 22:193-199. 
10. Hasenhuttle, B. L. and P. J. Wan. 1992. Temperature effects on the determination of oxidative stability with the Metrohm Rancimat. J. Am. Oil Chem. Soc., $69(6): 525-527$.

11. Hemeda, H. M. 1994. Isolation of natural antioxidants from vegetables waste by products . J. Agric. Sci. , Mansoura Univ., 19(9): 2953-2960.

12. Hussein, Fayza M. 2002. Utilization of some food industrial wastes. PhD. Thesis, Fac. of Agric. , Ain Shams Univ. , Egypt .

13. James, C.S. 1995 . Analytical chemistry of foods . Chap. 6 , General Food Studies ,First ed. , The Alden Press, Oxford, UK.

14. Kaur, C. and H. Kapoor. 2002. Anti-oxidant activity and total phenolic content of some Asian vegetables. International J. of Food Sci. and Tech. , 37:153- 161 .

15. Persia, M., C. Parsons, M. Schfang and J. Azcona. 2003. Nutritional evaluation of dried tomato seeds. Poultry Sci. , 82(1):141-146.

16. Radwan, H. M., G. A. Abd El-Malak and E. M. Mohamed. 2004. Effect of tomato peel pigments and some natural antioxidants on oxidative stability of sunflower oil . Egypt. J. Agric. Sci. , 82(4):1775-1785.

17. Ranganna, S. 1979 . Manual of analysis of fruit and vegetable products . Chaps.(2,4), Pectin , Plant Pigments . Tata McGraw-Hill Publishing Co. Ltd. , New Delhi , India., pp 29-79.

18. Sogi, D. S., Isnminder-Kaur and Amadeep-Batra. 2004. Utilization of nonconventional tomato ( Lycopersicon esculentum L. ) seed oil in mayonnaise . J. Food Sci. Tech. , 41(1):47-50.

19. Toor, R. K. and G. P. Savage. 2005. Antioxidant activity in different fractions of tomatoes. Food Res. International , 38: 487-494.

20. Zygadlo, J. A., R. E. Morere, R. E. Abburra and C. A. Guzman. 1994. Fatty acids composition in seeds oils of some onagracaeae. J. Am. Oil Chem. Soc. , 71(8):915-916. 


\section{الاستفادة من مخلفات الخوخ والطماطم كمدر غير تقليدي للزيوت الغذائية}

\section{ومضادات الأكسدة الطبيعية}

أمل محمد البسطويسي' ، أحمد عبد العزيز الرفاعى" ، محد زكريا محمد مصطقى'

$$
\begin{aligned}
& \text { 1. . معزل بحوث تكنولوجبيا الأغنية- مركز البحوث الزراعية- الجيزة }
\end{aligned}
$$

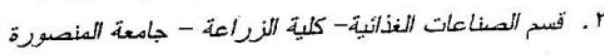

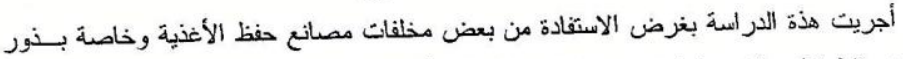

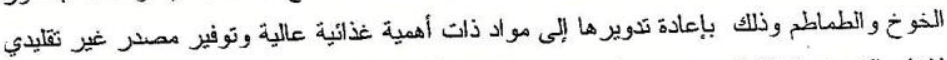

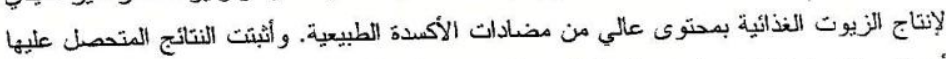

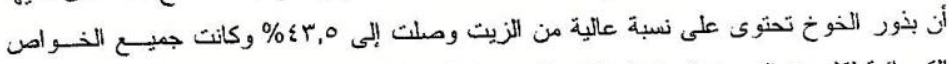

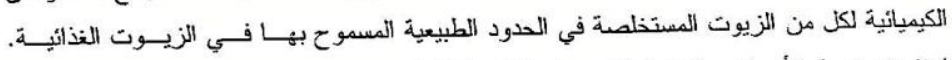

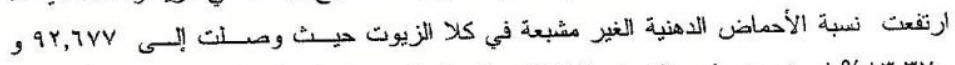
.

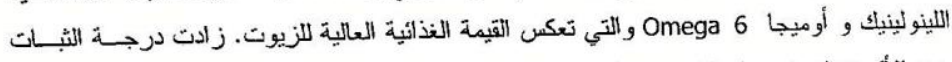

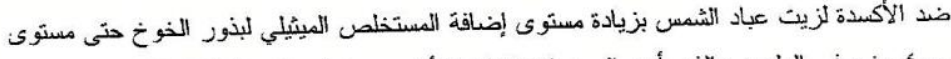

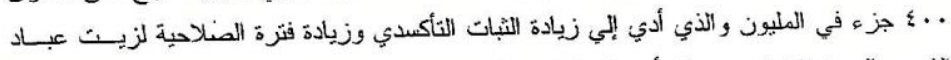

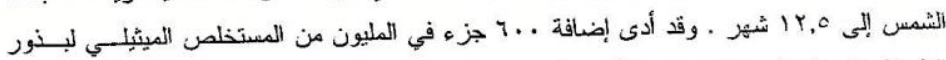

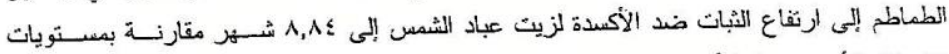

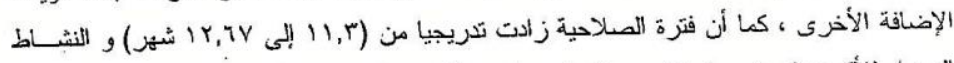

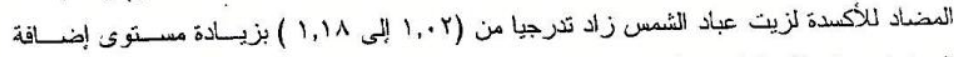

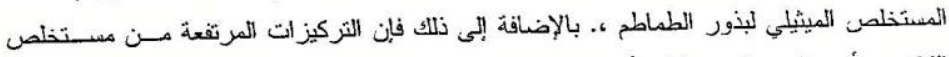

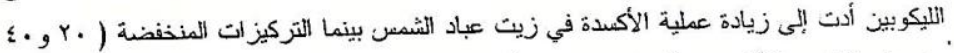
جزء في المليون ) أظهرت تأثبرات مضادة للأكسدة .

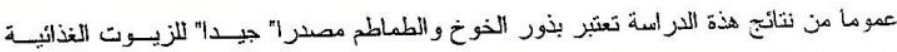

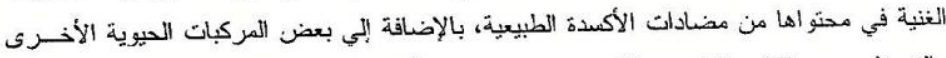

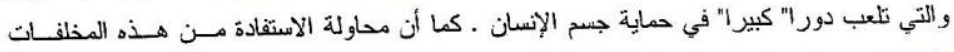

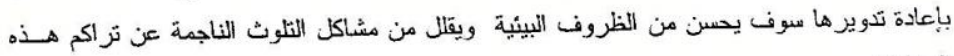

